\title{
Prognostic biomarkers in predicting mortality in respiratory patients with ventilator-associated pneumonia
}

\author{
Nermeen A. Abdelaleem ${ }^{*}$ (D), Hoda A. Makhlouf ${ }^{1}$, Eman M. Nagiub² and Hassan A. Bayoumi ${ }^{1}$
}

\begin{abstract}
Background: Ventilator-associated pneumonia (VAP) is the most common nosocomial infection. Red cell distribution width (RDW) and neutrophil-lymphocyte ratio (NLR) are prognostic factors to mortality in different diseases. The aim of this study is to evaluate prognostic efficiency RDW, NLR, and the Sequential Organ Failure Assessment (SOFA) score for mortality prediction in respiratory patients with VAP.

Results: One hundred thirty-six patients mechanically ventilated and developed VAP were included. Clinical characteristics and SOFA score on the day of admission and at diagnosis of VAP, RDW, and NLR were assessed and correlated to mortality. The average age of patients was $58.80 \pm 10.53$. These variables had a good diagnostic performance for mortality prediction AUC 0.811 for SOFA at diagnosis of VAP, 0.777 for RDW, 0.728 for NLR, and 0.840 for combined of NLR and RDW. The combination of the three parameters demonstrated excellent diagnostic performance (AUC 0.889). A positive correlation was found between SOFA at diagnosis of VAP and RDW $(r=0.446$, $P<0.000)$ and with NLR $(r=0.220, P<0.010)$.
\end{abstract}

Conclusions: NLR and RDW are non-specific inflammatory markers that could be calculated quickly and easily via routine hemogram examination. These markers have comparable prognostic accuracy to severity scores. Consequently, RDW and NLR are simple, yet promising markers for ICU physicians in monitoring the clinical course, assessment of organ dysfunction, and predicting mortality in mechanically ventilated patients. Therefore, this study recommends the use of blood biomarkers with the one of the simplest ICU score (SOFA score) in the rapid diagnosis of critical patients as a daily works in ICU.

Keywords: Red cell distribution width (RDW), Ventilator-associated pneumonia (VAP), Mortality, Neutrophil-tolymphocyte ratio (NLR), Sequential Organ Failure Assessment (SOFA) score, Respiratory, Mortality

\section{Background}

Ventilator-associated pneumonia (VAP) defined as pneumonia developed after endotracheal tube intubation/mechanical ventilation for more than $48 \mathrm{~h} \mathrm{[1].} \mathrm{It} \mathrm{is}$ the commonest nosocomial infection in intensive care units (ICU) $[2,3]$.

VAP continues to be a leading cause of morbidity and mortality in the nosocomial setting [4-7]. For those

\footnotetext{
* Correspondence: nermeenabdelaleem@gmail.com

'Department of Chest, Assiut University Hospital, Assiut University, Assiut, Egypt

Full list of author information is available at the end of the article
}

patients who are at risk of acquiring VAP, the likelihood of dying is twice as high as that observed in ventilated patients without VAP, with mortality rates ranging from 33 to $50 \%[4,8,9]$. The clinical value of scores and biomarkers are limited in diagnosis and prognosis [10].

The Sequential Organ Failure Assessment (SOFA) score is a simple and prognostic score that can calculate both the number and the severity of organ dysfunction in six organ systems (respiratory, coagulator, liver, cardiovascular, renal, and neurologic) [11]. Patients with a higher SOFA score mostly have a higher mortality rate [12].

\section{SpringerOpen}

(- The Author(s). 2021 Open Access This article is licensed under a Creative Commons Attribution 4.0 International License, which permits use, sharing, adaptation, distribution and reproduction in any medium or format, as long as you give appropriate credit to the original author(s) and the source, provide a link to the Creative Commons licence, and indicate if changes were made. The images or other third party material in this article are included in the article's Creative Commons licence, unless indicated otherwise in a credit line to the material. If material is not included in the article's Creative Commons licence and your intended use is not permitted by statutory regulation or exceeds the permitted use, you will need to obtain permission directly from the copyright holder. To view a copy of this licence, visit http://creativecommons.org/licenses/by/4.0/. 
Red blood cell distribution width (RDW) is a quantitative measure for size variability of circulating erythrocytes detected in a complete blood count (CBC) [13, 14]. RDW calculated by dividing the standard deviation (SD) of the mean corpuscular volume (MCV) by the $\mathrm{MCV}$ and multiplying by 100 to yield a percentage value to be on behalf of the RBC size heterogeneity [15]. Also, it is an inexpensive easily reasonable measurement that acts as a prognostic factor in several diseases [15].

Raised RDW associated with worse prognosis in numerous non-infectious [16-21], infectious diseases [2224], and sepsis and septic shock [25-28]. The definite pathophysiologic mechanism is still uncertain, but systemic factors that affect erythrocyte homeostasis such as inflammation and oxidative stress, essential components in infection cascade, seem to have an important role [29-31].

The neutrophil-to-lymphocyte ratio (NLR) is a systemic inflammation indicato $r[32,33]$. NLR is the number of neutrophils divided by the number of lymphocytes. The physiological immune response of leucocytes to stress is characterized by increasing neutrophils and decreasing lymphocytes [34]. Recently, NLR has been shown to be a prognostic marker in various diseases, such as solid tumors [34-36], cardiovascular disease $[34,37]$, and chronic obstructive pulmonary disease (COPD) [34, 38]. Besides, NLR became an independent indicator of mortality $[34,39,40]$. The NLR proved to be a simple and even better marker in expecting bacteremia than other parameters as C-reactive protein (CRP) level and white blood cell (WBC) count [41, 42].

\section{The aim of this study}

The goal of this study was to evaluate the prognostic efficiency of red blood cell distribution width (RDW), the neutrophil-lymphocyte ratio (NLR), and the Sequential Organ Failure Assessment (SOFA) score for mortality prediction in respiratory patients with VAP.

\section{Methods}

This study was a prospective observational analytic cohort study with no intervention. It was conducted over a period from April 2018 to December 2019 in the respiratory ICU in a tertiary hospital.

Inclusion criteria are as follows:

1. Age $>18$ years old

2. Respiratory failure needs mechanical ventilator support $>48 \mathrm{~h}$. VAP was defined as an acute lower respiratory tract infection in mechanically ventilated patient $>48 \mathrm{~h}$ with a new or progressing infiltrate on chest radiograph and who met at least two of the following clinical criteria: body temperature > $38^{\circ} \mathrm{C}$ or $<36{ }^{\circ} \mathrm{C}$ with no other recognized cause, white blood cell count $>10,000 / \mathrm{mm}^{3}$ or $<5000 /$ $\mathrm{mm}^{3}$, or a macroscopically purulent tracheal aspirate $[1,4]$.

3. Only the first VAP episode was included.

\section{Exclusion criteria are as follows:}

1. Neutropenia $(<500$ cells $/ \mathrm{ml})$ before the development of VAP.

2. Conditions are known to influence total and differential WBC counts such as chronic inflammatory conditions, hematologic disorders, history of chemotherapy, or radiotherapy within 4 weeks before enrollment.

3. Conditions are known to affect RDW as anemia due to nutritional deficiency (i.e., iron, vitamin B12, and folic acid). RDW tends to be high in nutritional deficiencies [43] as iron (demonstrated as low MCV $<80 \mathrm{fl}$ [44]) and in B12 and folic acid deficiencies (demonstrated as high MCV > $100 \mathrm{fl}[44]$ ); those patients were excluded from the study by evaluating their $\mathrm{CBC}$ blood indices as $\mathrm{MCV}$ and $\mathrm{MCH}$.

\section{Patients with HIV/AIDS}

For all patients, demographic parameters (age and gender), vital signs, Glasgow Coma Scale (GCS), laboratory results (complete blood counts: WBC count, neutrophil count, lymphocyte count and NLR (absolute neutrophil count divided by absolute lymphocyte count), RDW, serum creatinine, albumin, and arterial blood gas tests) at time of VAP diagnosis. The SOFA score was calculated at admission to the ICU and on the day of the diagnosis of VAP. Pulmonary X-rays were taken. Intensive care unit (ICU) length of stay, duration of mechanical ventilation before developing VAP, and total ICU stays.

For all patients in whom the clinical suspicion of VAP was confirmed, empirical antimicrobial therapy was started on the first day. Antibiotic therapy has been selected by the critical care team. The outcome of interest was in-hospital mortality or survival.

\section{Laboratory assessment}

Hematological parameters were determined by automated CBC analyzer "Cell Dyne Ruby" (Abbott, Diagnostic ${ }^{\circ}$ ). The RDW values were obtained as part of the $\mathrm{CBC}$ results. The normal reference value ranges in our hospital laboratory are for RDW $11.6-14.8 \%$ and for NLR between 0.78 and 3.53 .

\section{Statistical analysis}

Data were represented as median \pm SD or medians and ranges. Categorical variables were compared with the 
chi-square test or Fisher's exact test. Comparison of continuous variables between the two groups was performed using the Mann-Whitney $U$ test. The area under the ROC curve (AUC) was calculated for each marker, and the standard error and 95\% confidence interval (95\% CI) were determined. The overall discrimination performance of a given test is measured by calculating the area under the ROC curve (AUC). AUC is a powerful method to summarize the overall diagnostic accuracy of the test. The value of AUC ranges from 0.5 (no discrimination) to 1 (perfect discrimination). In all tests, $P<0.05$ was considered statistically significant difference. Statistical analysis was performed using the SPSS version 20.0 software package (IBM SPSS, Armonk, NY, USA).

\section{Results}

A total of 136 patients (63.9\% men, 36\% women) with a mean age $(58.80 \pm 10.53)$ were included in the study. The mean length of ICU stay was $15.76 \pm 5.72$ days, and 54 patients (39.7\%) died during hospitalization. Comparative baseline values of demographic, main laboratory findings, and severity of disease between enrolled patients (82 surviving and 54 non-surviving) were listed in Table 1.

The current study demonstrated that, non-survivors were more likely to be elderly with higher $\mathrm{WBC}$ and creatinine and lower albumin without statistical significance. Moreover, non-survivors group had significantly higher RDW and NLR than survivors at the time of VAP diagnosis (mean $\pm \mathrm{SD}, 15.75 \pm 3.19$ versus $12.94 \pm 1.87$ in survivors for the former and $11.43 \pm 3.76$ versus $8.51 \pm$ 3.74 in non-survivors for the latter). SOFA score at admission, SOFA at diagnosis of VAP, the duration of mechanical ventilation, time of occurrence of VAP, and total ICU stay were significantly higher in non-survivors group compared to survivors group $(P<0.05$ for each).

The ROC curve analysis to predict in-hospital mortality showed AUC 0.728 (95\% confidence interval [CI] (0.6420.815)) for NLR (Fig. 1) and 0.777 (95\% CI, 0.696-0.859) for RDW (Fig. 2), 0.764 (95\% CI, 0.683-0.845) for SOFA at admission (Fig. 3a), 0.811 (95\% CI, 0.725-0.897) for SOFA at diagnosis of VAP as shown in (Fig. 3b). The AUCs were significantly increased when RDW was added to NLR 0.840 (95\% CI, 0.773-0.907; $P, 0.000$ ). If the three variables were combined, it gave excellent AUC, 0.889 (95\% CI, 0.883-0.946; P, 0.000) (Fig. 4a, b).

A positive correlation was found between SOFA score at diagnosis of VAP and NLR $(r, 0.220 ; P, 0.010)$, and between SOFA score and RDW $(r, 0.446 ; P, 0.000)$ (Fig. $5 \mathrm{a}, \mathrm{b})$.

\section{Discussion}

Pneumonia is the most common nosocomial infection in patients admitted to ICU [45]. Several serum markers expressed when patients exposed to bacterial toxins.
Changes in the levels of biomarkers could signal a change in clinical status [46].

This study assessed 136 patients diagnosed as VAP; the mortality rate was $39.7 \%$ that was consistent with the American Thoracic Society, and Infectious Diseases Society of America guideline [1] that reported mortality range from 33 to $50 \%$.

In agreement with other studies [47-50], the current study showed a male sex predominance. The age of the study patients was higher in the non-survivors group. Blot et al. and other studies [51, 52] concluded that VAP mortality more with the elderly.

SOFA score helped to predict the severity status and impact of organ failure on the mortality outcome. The admission SOFA score used to assess the degree of organ dysfunction, so it can organize patients into risk categories. While SOFA score taken at time of diagnosis of VAP is prognostic tool. The highest score can diagnose of highest point of multiorgan dysfunction. SOFA was easy to calculate with less data collection. Change in SOFA at the time of diagnosis was a valid tool for the assessment of mortality in different critical illnesses [5357]. There was a significantly higher SOFA score at diagnosis of VAP in non-survivors in comparison with survivors in this study. These results were consistent with Vincent et al. [58], Ferreira et al. [53], and several other studies [12, 59-61].

In ROC analysis, AUC was 0.81 in the current study, Karakuzu et al. [60] found an AUC 0.821 for SOFA score at the time of VAP diagnosis in mortality predicting. This was also similar to the values obtained in other earlier studies (AUC ranging from 0.72 to 0.89) [60]. Hence, calculating the SOFA score at the time of VAP diagnosis may provide valuable information for mortality prognosis.

Inflammation and oxidative stress affect red cell homeostasis. So RDW showed a strong association with inflammatory biomarkers [13, 62]. The current study showed that higher RDW was statistically significantly associated with increased hospital mortality. This is in accordance with Zhang et al.'s [63] study that was done on critically ill patients mixed ICU of a tertiary teaching hospital. Several studies [28, 64, 65] on patients with sepsis found that RDW considered a clinical importance marker in sepsis management and mortality predication. Lee et al. concluded that RDW was a valuable prognostic marker for mortality in patient with communityacquired pneumonia [62]. In a cohort study done by Chen et al. [66], they found that RDW, albumin level, age, and serum creatinine were independent predictors of mortality in with community-acquired pneumonia. Another retrospective cohort study on pediatric patients reported that the value of RDW on admission was associated with the need for invasive mechanical ventilation 
Table 1 Demographic characteristics, laboratory, and disease severity for the study population

\begin{tabular}{|c|c|c|c|c|}
\hline Variable & Total, $n$ (136) & Survivor, $n$ (82) & Non-survivor, $n$ (54) & $P$ value \\
\hline Age (year) & $58.80 \pm 10.53$ & $57.68 \pm 11.30$ & $60.50 \pm 9.06$ & 0.127 \\
\hline \multicolumn{5}{|l|}{ Sex } \\
\hline Male & $87(63.9 \%)$ & $55(67.1 \%)$ & $32(59.3 \%)$ & \multirow[t]{2}{*}{0.368} \\
\hline Female & $49(36 \%)$ & $27(32.9 \%)$ & $22(40.7 \%)$ & \\
\hline WBC $\left(\times 1000 / \mathrm{mm}^{3}\right)$ & $12.87 \pm 4.74$ & $12.73 \pm 4.28$ & $13.97 \pm 5.41$ & 0.685 \\
\hline $\mathrm{Hg}(\mathrm{gm} / \mathrm{dl})$ & $12.11 \pm 2.19$ & $12.51 \pm 2.03$ & $11.65 \pm 2.22$ & 0.022 \\
\hline $\operatorname{PLT}\left(\times 1000 / \mathrm{mm}^{3}\right)$ & $205.27 \pm 104.27$ & $210.36 \pm 75.36$ & $197.54 \pm 137.52$ & 0.419 \\
\hline RDW (\%) & $14.06 \pm 2.83$ & $12.94 \pm 1.87$ & $15.75 \pm 3.19$ & 0.000 \\
\hline NLR (\%) & $9.67 \pm 4.00$ & $8.51 \pm 3.74$ & $11.43 \pm 3.76$ & 0.000 \\
\hline Serum urea $(\mathrm{mg} / \mathrm{dL})$ & $9.75 \pm 5.15$ & $6.54 \pm 3.29$ & $11.42 \pm 5.19$ & 0.008 \\
\hline Serum creatinine $(\mu \mathrm{mol} / \mathrm{L})$ & $120.56 \pm 70.11$ & $112.94 \pm 68.24$ & $132.36 \pm 71.97$ & 0.116 \\
\hline Serum albumin (g/L) & $24.68 \pm 9.90$ & $25.70 \pm 10.45$ & $23.11 \pm 8.86$ & 0.139 \\
\hline SOFA score at admission & $4.25 \pm 1.79$ & $3.68 \pm 1.39,3(2-7)$ & $5.41 \pm 1.92,5(2-10)$ & 0.000 \\
\hline SOFA score at diagnosis of VAP & $5.67 \pm 2.38$ & $4.60 \pm 1.48,4(3-10)$ & $7.30 \pm 2.56,8(2-11)$ & 0.000 \\
\hline Duration of mechanical ventilation (days) & $12.49 \pm 4.95$ & $11.12 \pm 3.74$ & $14.57 \pm 5.81$ & 0.000 \\
\hline Time of occurrence of VAP (days) & $6.25 \pm 2.58$ & $5.56 \pm 2.37$ & $7.17 \pm 2.63$ & 0.001 \\
\hline Length of ICU stay (days) & $15.76 \pm 5.72$ & $13.89 \pm 4.53$ & $18.61 \pm 6.18$ & 0.000 \\
\hline
\end{tabular}

WBC white blood count, $\mathrm{Hg}$ hemoglobin, PLT platelet, $R D W$ red cell distribution width, NLR neutrophilic lymphocyte ratio, SOFA Sequential Organ Failure Assessment Score, VAP ventilator-associated pneumonia, ICU intensive care unit

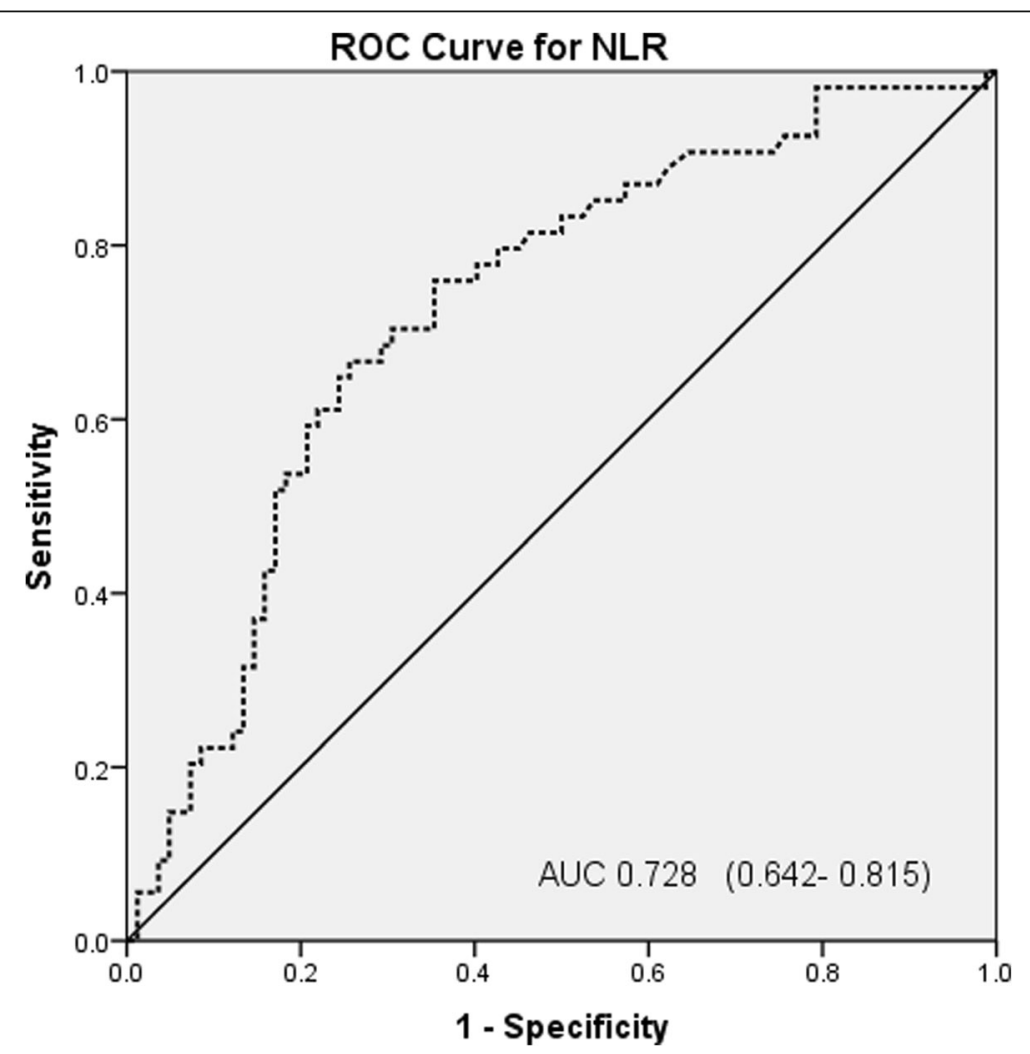

Fig. 1 ROC for NLR 


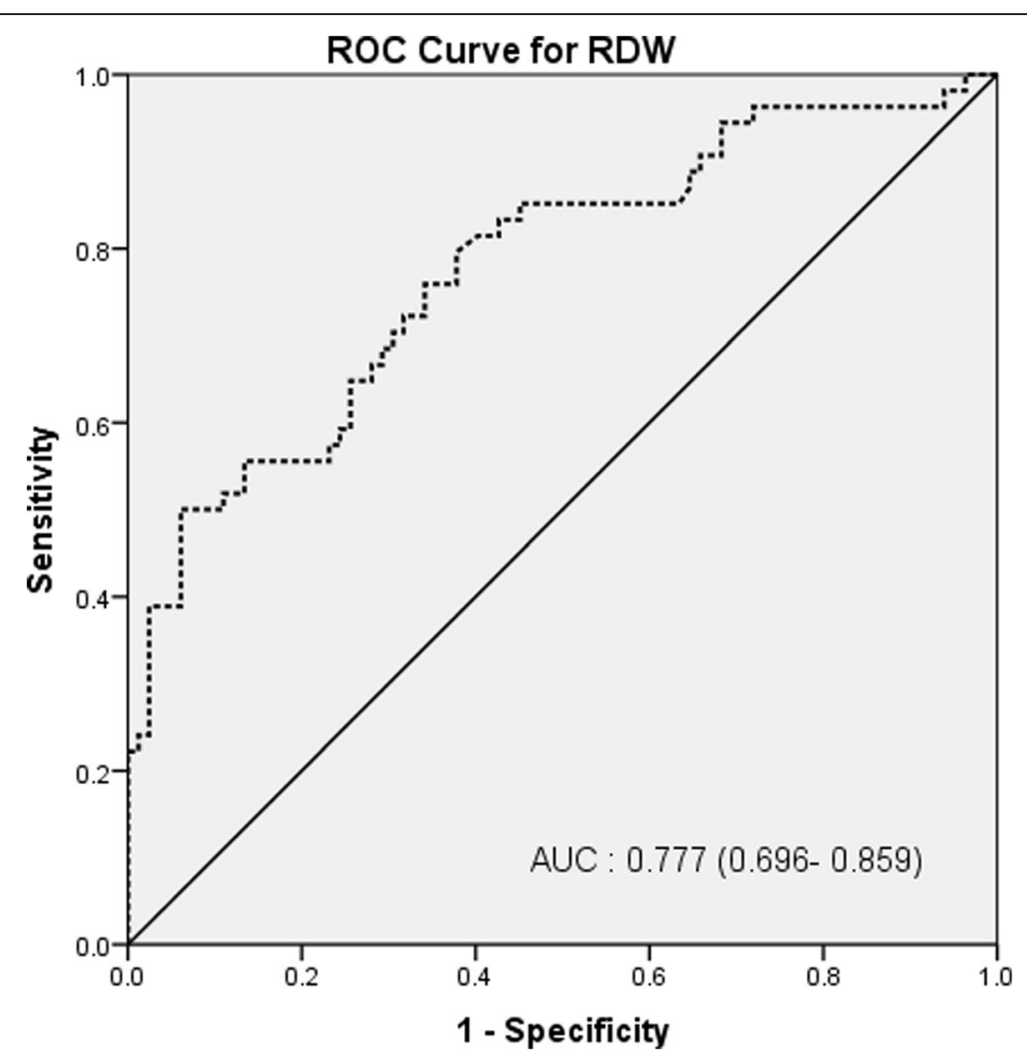

Fig. 2 ROC for RDW

and a prognostic parameter of respiratory failure in the pediatric ICU [67].

Neutrophils and other inflammatory cells mediate patients' pro-inflammatory state in infection $[12,68]$. The augmented innate response with neutrophilmediated killing can suppress apoptosis of neutrophil and thus, neutrophils rising and lymphocytes apoptosis [69, 70]. Recently, the neutrophil/lymphocyte ratio (NLR) has been recorded to mortality prognosis in CAP [42, 71]. Jager et al. [42] study showed elevated NLR in patients with CAP and even higher levels among patients who died in hospital with AUC 0.701. Their study concluded that NLR predicts the severity and outcome of CAP with high prognostic

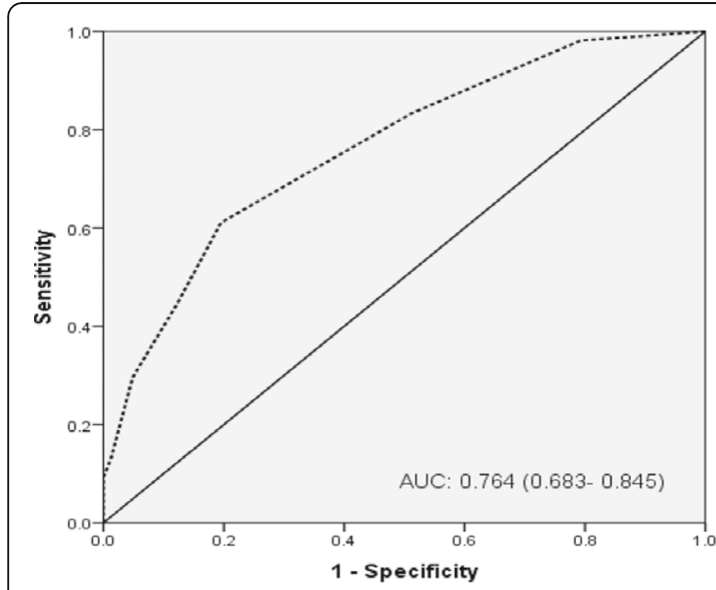

(A): ROC for SOFA at admission

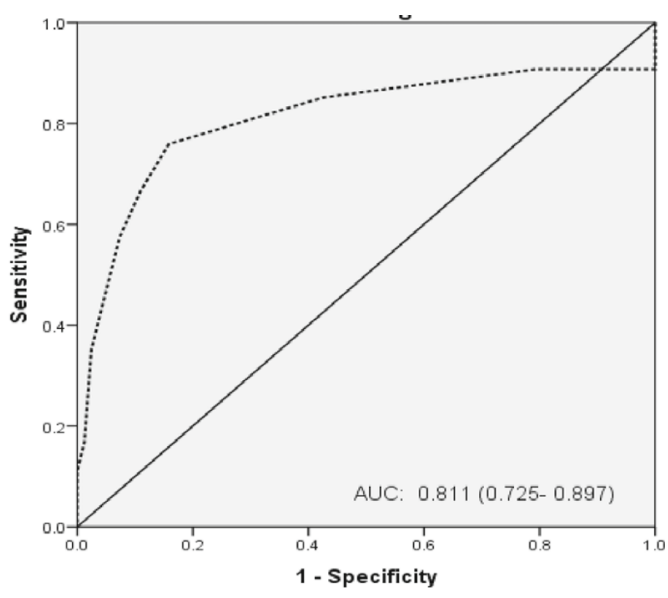

(B): ROC for SOFA at diagnosis of VAP

Fig. 3 a ROC for SOFA at admission. $\mathbf{b}$ ROC for SOFA at diagnosis of VAP 


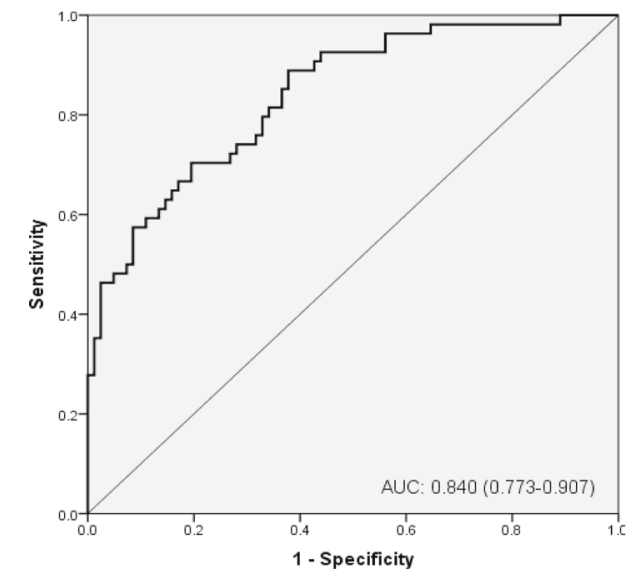

(A): ROC for combined RDW and NLR

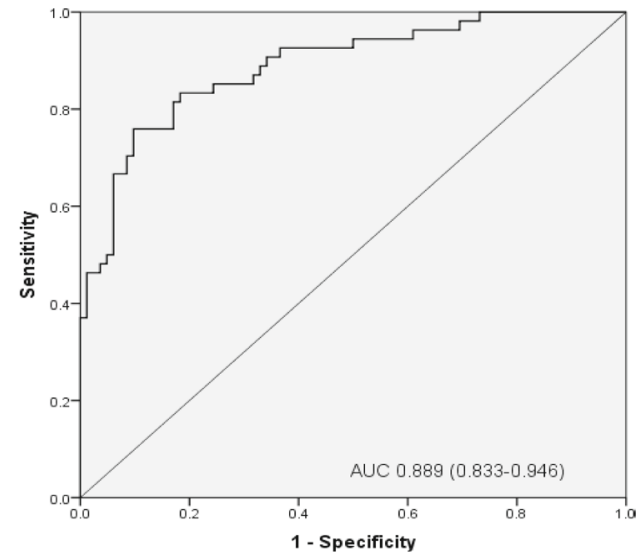

(B): ROC for combined three variables

Fig. 4 a ROC for combined RDW and NLR. b ROC for combined three variables

accuracy in comparison with other classic markers of infection.

To the best of our knowledge, few studies have assessed the NLR value in VAP. Feng et al. [12] showed a reasonable performance of high NLR as a prognostic factor of 30-day mortality in VAP. The present study showed good predictive discrimination for mortality (AUC, 0.729). So NLR may help physicians to rapidly classify patients into different prognostic groups, to reduce VAP mortality $[12,72]$.

The present study has several strengths. To our knowledge, this was the first study that predicts mortality for respiratory patients with VAP by using blood biomarkers either RDW, NLR, or both with good performance. Furthermore, this study found a positive correlation between one of the most important ICU scores (SOFA score) and both blood biomarkers (RDW and NLR). So it suggests that RDW and NLR, which is quickly performed, may act as the scoring systems in determining high-risk patients with VAP.

\section{Limitation of the study}

This study was done in a single tertiary hospital and there may be local differences between centers and institutions.

\section{Conclusion}

NLR and RDW are non-specific inflammatory markers that could be calculated quickly and easily via routine hemogram examination. These markers have comparable prognostic accuracy to severity scores. Consequently, RDW and NLR are simple yet promising markers for ICU physicians in monitoring the clinical course, assessment of organ dysfunction, and predicting mortality in mechanically ventilated patients. Therefore, this study recommends the use of blood biomarkers with the one of the simplest ICU score (SOFA score) in the rapid diagnosis of critical patients as a daily works in ICU.

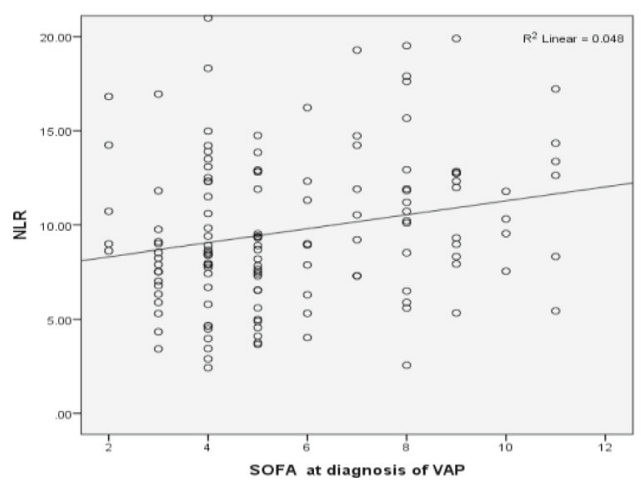

(A): Correlation between NLR and SOFA

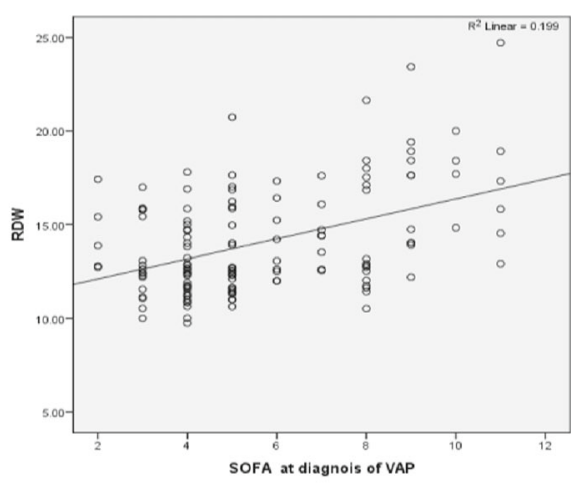

(B): Correlation between RDW and SOFA

Fig. 5 a Correlation between NLR and SOFA. b Correlation between RDW and SOFA 


\section{Abbreviations}

VAP: Ventilator-associated pneumonia; RDW: Red cell distribution width; NLR: Neutrophil-lymphocyte ratio; SOFA: Sequential Organ Failure Assessment; ICU: Intensive care units; CBC: Complete blood count; CRP: Creactive protein level; WBC: White blood cell; MCV: mean corpuscular volume; COPD: Chronic obstructive pulmonary disease; GCS: Glasgow Coma Scale

\section{Acknowledgements}

Not applicable.

\section{Authors' contributions}

$\mathrm{NA}, \mathrm{HM}, \mathrm{EN}$, and $\mathrm{HB}$ jointly conceived the study and contributed to data acquisition, and NA the analysis and interpretation of the data. All authors reviewed the manuscript prior to submission and all accept responsibility for the integrity of the research process and findings. All authors read and approved the final manuscript.

\section{Funding}

Not applicable.

\section{Availability of data and materials}

The data sets generated and/or analyzed during the present study are not publicly available, but they are available from the corresponding author on reasonable request.

\section{Declarations}

\section{Ethics approval and consent to participate}

The study was approved by an Assiut University Ethics Committee. Written informed consent obtained from their next of kin, because of the patient's critical condition. Number IRB 17300520.

Clinical trial registration number: NCT04739748

\section{Consent for publication}

Not applicable.

\section{Competing interests}

The authors declare no competing interests.

\section{Author details}

'Department of Chest, Assiut University Hospital, Assiut University, Assiut, Egypt. ${ }^{2}$ Department of Clinical Pathology, Assiut University Hospital, Assiut University, Assiut, Egypt.

Received: 28 November 2020 Accepted: 3 March 2021 Published online: 18 March 2021

\section{References}

1. Society AT, America IDSo (2005) Guidelines for the management of adults with hospital-acquired, ventilator-associated, and healthcare-associated pneumonia. Am J Respir Crit Care Med 171(4):388

2. Huang K-T, Tseng C-C, Fang W-F, Lin M-C (2010) An early predictor of the outcome of patients with ventilator-associated pneumonia. Chang Gung Med J 33(3):274-282

3. Wu D, Wu C, Zhang S, Zhong Y (2019) Risk factors of ventilator-associated pneumonia in critically III patients. Front Pharmacol 10:482

4. Chastre J, Fagon J-Y (2002) Ventilator-associated pneumonia. Am J Respir Crit Care Med 165(7):867-903

5. Weinstein RA, Bonten MJ, Kollef MH, Hall JB (2004) Risk factors for ventilator associated pneumonia: from epidemiology to patient management. Clin Infect Dis 38(8):1141-1149

6. $\quad$ Sinuff T, Muscedere J, Cook D, Dodek P, Heyland D, Group CCCT (2008) Ventilator-associated pneumonia: improving outcomes through guideline implementation. J Crit Care 23(1):118-125

7. Mirsaeidi M, Peyrani P, Ramirez JA, Investigators IMtPAoCToH-AP (2009) Predicting mortality in patients with ventilator-associated pneumonia: the APACHE II score versus the new IBMP-10 score. Clin Infect Dis 49(1):72-77

8. Furtado G, Wiskirchen D, Kuti J, Nicolau D (2012) Performance of the PIRO score for predicting mortality in patients with ventilator-associated pneumonia. Anaesth Intensive Care 40(2):285-291
9. Xu Y, Lai C, Xu G, Meng W, Zhang J, Hou H et al (2019) Risk factors of ventilator-associated pneumonia in elderly patients receiving mechanical ventilation. Clin Interv Aging 14:1027

10. Torres A, Ewig S, Lode H, Carlet J, Group EHW (2009) Defining, treating and preventing hospital acquired pneumonia: European perspective. Intensive Care Med 35(1):9-29

11. Jones AE, Trzeciak S, Kline JA (2009) The Sequential Organ Failure Assessment score for predicting outcome in patients with severe sepsis and evidence of hypoperfusion at the time of emergency department presentation. Crit Care Med 37(5):1649

12. Feng D-Y, Zhou Y-Q, Zhou M, Zou X-L, Wang Y-H, Zhang T-T (2019) Risk factors for mortality due to ventilator-associated pneumonia in a Chinese hospital: a retrospective study. Med Sci Monit 25:7660

13. Bazick HS, Chang D, Mahadevappa K, Gibbons FK, Christopher KB (2011) Red Cell Distribution width and all cause mortality in critically ill patients. Crit Care Med 39(8):1913

14. Bessman JD, Gilmer JRPR, Gardner FH (1983) Improved classification of anemias by MCV and RDW. Am J Clin Pathol 80(3):322-326

15. Clarke K, Sagunarthy R, Kansal S (2008) RDW as an additional marker in inflammatory bowel disease/undifferentiated colitis. Dig Dis Sci 53(9): $2521-2523$

16. Ani C, Ovbiagele B (2009) Elevated red blood cell distribution width predicts mortality in persons with known stroke. J Neurol Sci 277(1-2):103-108

17. Hampole CV, Mehrotra AK, Thenappan T, Gomberg-Maitland M, Shah SJ (2009) Usefulness of red cell distribution width as a prognostic marker in pulmonary hypertension. Am J Cardiol 104(6):868-872

18. Sangoi MB, Da Silva SH, da Silva JEP, Moresco RN (2011) Relation between red blood cell distribution width and mortality after acute myocardial infarction. Int J Cardiol 146(2):278-280

19. Oh HJ, Park JT, Kim J-K, Yoo DE, Kim SJ, Han SH et al (2012) Red blood cell distribution width is an independent predictor of mortality in acute kidney injury patients treated with continuous renal replacement therapy. Nephrol Dial Transplant 27(2):589-594

20. Seyhan EC, Özgül MA, Tutar N, Im Ö, Uysal A, Altın S (2013) Red blood cell distribution and survival in patients with chronic obstructive pulmonary disease. COPD: J Chron Obstruct Pulmon Dis 10(4):416-424

21. Bilal A, Farooq JH, Kiani I, Assad S, Ghazanfar H, Ahmed I (2016) Importance of mean red cell distribution width in hypertensive patients. Cureus 8:11

22. Guray Y, Ipek EG, Guray U, Demirkan B, Kafes H, Asarcikli LD et al (2014) Red cell distribution width predicts mortality in infective endocarditis. Arch Cardiovasc Dis 107(5):299-307

23. Bello S, Fandos S, Lasierra A, Mincholé E, Panadero C, Simon A et al (2015) Red blood cell distribution width [RDW] and long-term mortality after community-acquired pneumonia. A comparison with proadrenomedullin. Respir Med 109(9):1193-1206

24. Braun E, Kheir J, Mashiach T, Naffaa M, Azzam ZS (2014) Is elevated red cell distribution width a prognostic predictor in adult patients with community acquired pneumonia? BMC Infect Dis 14(1):129

25. Lorente L, Martín MM, Abreu-González P, Solé-Violán J, Ferreres J, Labarta L et al (2014) Red blood cell distribution width during the first week is associated with severity and mortality in septic patients. PloS one 9(8): e105436

26. Sadaka F, O'Brien J, Prakash S (2013) Red cell distribution width and outcome in patients with septic shock. J Intensive Care Med 28(5):307-313

27. Kim S, Lee K, Kim I, Jung S, Kim M-J (2015) Red cell distribution width and early mortality in elderly patients with severe sepsis and septic shock. Clin Exp Emerg Med 2(3):155

28. Jandial A, Kumar S, Bhalla A, Sharma N, Varma N, Varma S (2017) Elevated red cell distribution width as a prognostic marker in severe sepsis: a prospective observational study. Indian J Crit Care Med 21(9):552

29. Pierce CN, Larson DF (2005) Inflammatory cytokine inhibition of erythropoiesis in patients implanted with a mechanical circulatory assist device. Perfusion 20(2):83-90

30. Semba RD, Patel KV, Ferrucci L, Sun K, Roy CN, Guralnik JM et al (2010) Serum antioxidants and inflammation predict red cell distribution width in older women: the Women's Health and Aging Study I. Clin Nutr 29(5):600-604

31. Lippi G, Targher G, Montagnana M, Salvagno GL, Zoppini G, Guidi GC (2009) Relation between red blood cell distribution width and inflammatory biomarkers in a large cohort of unselected outpatients. Arch Pathol Lab Med 133(4):628-632 
32. Zahorec R (2001) Ratio of neutrophil to lymphocyte counts-rapid and simple parameter of systemic inflammation and stress in critically ill. Bratisl Lek Listy 102(1):5-14

33. Xue J, Huang W, Chen X, Li Q, Cai Z, Yu T et al (2017) Neutrophil-tolymphocyte ratio is a prognostic marker in acute ischemic stroke. J Stroke Cerebrovasc Dis 26(3):650-657

34. Li W, Ai X, Ni Y, Ye Z, Liang Z (2019) The association between the neutrophilto-lymphocyte ratio and mortality in patients with acute respiratory distress syndrome: a retrospective cohort study. Shock 51(2):161-167

35. Gao F, Li X, Geng M, Ye X, Liu H, Liu Y et al (2015) Pretreatment neutrophillymphocyte ratio: an independent predictor of survival in patients with hepatocellular carcinoma. Medicine 94(11):e639

36. Walsh S, Cook E, Goulder F, Justin T, Keeling N (2005) Neutrophillymphocyte ratio as a prognostic factor in colorectal cancer. J Surg Oncol 91(3):181-184

37. Tamhane UU, Aneja S, Montgomery D, Rogers E-K, Eagle KA, Gurm HS (2008) Association between admission neutrophil to lymphocyte ratio and outcomes in patients with acute coronary syndrome. Am J Cardiol 102(6): 653-657

38. Furutate R, Ishii T, Motegi T, Hattori K, Kusunoki Y, Gemma A et al (2016) The neutrophil to lymphocyte ratio is related to disease severity and exacerbation in patients with chronic obstructive pulmonary disease. Intern Med 55(3):223-229

39. Hwang SY, Shin TG, Jo IJ, Jeon K, Suh GY, Lee TR et al (2017) Neutrophil-tolymphocyte ratio as a prognostic marker in critically-ill septic patients. Am J Emerg Med 35(2):234-239

40. Akilli NB, Yortanlı M, Mutlu H, Günaydın YK, Koylu R, Akca HS et al (2014) Prognostic importance of neutrophil-lymphocyte ratio in critically ill patients: short-and long-term outcomes. Am J Emerg Med 32(12):1476-1480

41. de Jager CP, van Wijk PT, Mathoera RB, de Jongh-Leuvenink J, van der Poll T, Wever PC (2010) Lymphocytopenia and neutrophil-lymphocyte count ratio predict bacteremia better than conventional infection markers in an emergency care unit. Crit Care 14(5):R192

42. de Jager CP, Wever PC, Gemen EF, Kusters R, van Gageldonk-Lafeber AB, van der Poll T et al (2012) The neutrophil-lymphocyte count ratio in patients with community-acquired pneumonia. PLoS One 7(10):e46561

43. García-Escobar A, Ingelmo JMG (2019) Red cell volume distribution width as another biomarker. Card Fail Rev 5(3):176

44. Buttarello M (2016) Laboratory diagnosis of anemia: are the old and new red cell parameters useful in classification and treatment, how? Int J Lab Hematol 38:123-132

45. Koenig SM, Truwit JD (2006) Ventilator-associated pneumonia: diagnosis, treatment, and prevention. Clin Microbiol Rev 19(4):637-657

46. Seligman R, Seligman B, Teixeira P (2011) Comparing the accuracy of predictors of mortality in ventilator-associated pneumonia. J Bras Pneumol 37(4):495-503

47. Rello J, Ollendorf DA, Oster G, Vera-Llonch M, Bellm L, Redman R et al (2002) Epidemiology and outcomes of ventilator-associated pneumonia in a large US database. Chest 122(6):2115-2121

48. Jaimes F, De La Rosa G, Gómez E, Múnera P, Ramírez J, Castrillón S (2007) Incidence and risk factors for ventilator-associated pneumonia in a developing country: where is the difference? Respir Med 101(4):762-767

49. Resende MM, Monteiro SG, Callegari B, Figueiredo PM, Monteiro CR, Monteiro-Neto V (2013) Epidemiology and outcomes of ventilatorassociated pneumonia in northern Brazil: an analytical descriptive prospective cohort study. BMC Infect Dis 13(1):119

50. de Miguel-Díez J, López-de-Andrés A, Hernández-Barrera $V$, Jiménez-Trujillo I, Méndez-Bailón M, de Miguel-Yanes JM et al (2017) Decreasing incidence and mortality among hospitalized patients suffering a ventilator-associated pneumonia: analysis of the Spanish national hospital discharge database from 2010 to 2014. Medicine 96(30):e7625

51. Blot S, Koulenti D, Dimopoulos G, Martin C, Komnos A, Krueger WA et al (2014) Prevalence, risk factors, and mortality for ventilator-associated pneumonia in middle-aged, old, and very old critically ill patients. Crit Care Med 42(3):601-609

52. Afifi MH, Elhendy AA, Eltaweel MM, Soliman NM, Elfeky EM, Salama AE (2015) Biomarker predictors of survival in patients with ventilator-associated pneumonia. Menoufia Med J 28(1):254

53. Ferreira FL, Bota DP, Bross A, Mélot C, Vincent J-L (2001) Serial evaluation of the SOFA score to predict outcome in critically ill patients. Jama 286(14): 1754-1758
54. Pettilä V, Pettilä M, Sarna S, Voutilainen P, Takkunen O (2002) Comparison of multiple organ dysfunction scores in the prediction of hospital mortality in the critically ill. Crit Care Med 30(8):1705-1711

55. Vincent J-L, Sakr Y, Sprung CL, Ranieri VM, Reinhart K, Gerlach H et al (2006) Sepsis in European intensive care units: results of the SOAP study. Crit Care Med 34(2):344-353

56. Lie KC, Lau C-Y, Chau NW, West TE, Limmathurotsakul D (2018) Utility of SOFA score, management and outcomes of sepsis in Southeast Asia: a multinational multicenter prospective observational study. J Intensive Care 6(1):9

57. Lambden S, Laterre PF, Levy MM, Francois B (2019) The SOFA score-development, utility and challenges of accurate assessment in clinical trials. Crit Care 23(1):1-9

58. Vincent J-L, Bihari DJ, Suter PM, Bruining HA, White J, Nicolas-Chanoin M-H et al (1995) The prevalence of nosocomial infection in intensive care units in Europe: results of the European Prevalence of Infection in Intensive Care (EPIC) Study. Jama 274(8):639-644

59. Inchai J, Pothirat C, Bumroongkit C, Limsukon A, Khositsakulchai W, Liwsrisakun C (2015) Prognostic factors associated with mortality of drugresistant Acinetobacter baumannii ventilator-associated pneumonia. J Intensive Care 3(1):9

60. Karakuzu Z, Iscimen R, Akalin H, Girgin NK, Kahveci F, Sinirtas M (2018) Prognostic risk factors in ventilator-associated pneumonia. Med Sci Monit 24:1321

61. da Silveira F, Nedel WL, Cassol R, Pereira PR, Deutschendorf C, Lisboa T (2019) Acinetobacter etiology respiratory tract infections associated with mechanical ventilation: what impacts on the prognosis? A retrospective cohort study. J Crit Care 49:124-128

62. Lee JH, Chung HJ, Kim K, Jo YH, Rhee JE, Kim YJ et al (2013) Red cell distribution width as a prognostic marker in patients with communityacquired pneumonia. Am J Emerg Med 31(1):72-79

63. Zhang Z, Xu X, Ni H, Deng H (2013) Red cell distribution width is associated with hospital mortality in unselected critically ill patients. J Thorac Dis 5(6):730

64. Wang A-Y, Ma H-P, Kao W-F, Tsai S-H, Chang C-K (2018) Red blood cell distribution width is associated with mortality in elderly patients with sepsis. Am J Emerg Med 36(6):949-953

65. Jo YH, Kim K, Lee JH, Kang C, Kim T, Park H-M et al (2013) Red cell distribution width is a prognostic factor in severe sepsis and septic shock. Am J Emerg Med 31(3):545-548

66. Chen L, Lu XY, Zhu CQ (2020) Prognostic value of albumin-red cell distribution width score in patients with severe community-acquired pneumonia. Ann Palliat Med 9(3):759-765

67. Schepens T, De Dooy JJ, Verbrugghe W, Jorens PG (2017) Red cell distribution width (RDW) as a biomarker for respiratory failure in a pediatric ICU. J Inflamm 14(1):12

68. Lowsby R, Gomes C, Jarman I, Lisboa P, Nee PA, Vardhan M et al (2015) Neutrophil to lymphocyte count ratio as an early indicator of blood stream infection in the emergency department. Emerg Med J 32(7):531-534

69. Zhou Y-Q, Feng D-Y, Li W-J, Yang H-L, Wang Z-N, Zhang T-T et al (2018) Lower neutrophil-to-lymphocyte ratio predicts high risk of multidrugresistant Pseudomonas aeruginosa infection in patients with hospitalacquired pneumonia. Ther Clin Risk Manag 14:1863

70. Drewry AM, Samra N, Skrupky LP, Fuller BM, Compton SM, Hotchkiss RS (2014) Persistent lymphopenia after diagnosis of sepsis predicts mortality. Shock (Augusta, Ga) 42(5):383

71. Curbelo J, Luquero Bueno S, Galván-Román JM, Ortega-Gómez M, Rajas O, Fernández-Jiménez G et al (2017) Inflammation biomarkers in blood as mortality predictors in community-acquired pneumonia admitted patients: importance of comparison with neutrophil count percentage or neutrophillymphocyte ratio. PLoS One 12(3):e0173947

72. Cataudella E, Giraffa CM, Di Marca S, Pulvirenti A, Alaimo S, Pisano M et al (2017) Neutrophil-to-lymphocyte ratio: an emerging marker predicting prognosis in elderly adults with community-acquired pneumonia. J Am Geriatr Soc 65(8):1796-1801

\section{Publisher's Note}

Springer Nature remains neutral with regard to jurisdictional claims in published maps and institutional affiliations. 